\title{
TINJAUAN YURIDIS TERHADAP HUKUMAN ANAK YANG MELAKUKAN TINDAK PIDANA KEKEJAMAN
}

\author{
Tina Asmarawati \\ Pascasarjana UNIS Tangerang \\ Email: tina.asmarawati@gmail.com
}

\begin{abstract}
ABSTRAK
Saat ini banyak tindak pidana yang dilakukan oleh anak dari yang ringan sampai yang berat.Tingkat Kualitas dan kuantitasnya semakin meningkat seperti kasusnarkoba.penganiayaan, pembunuhan, pencurian, maupun tindak pidana pencabulan. Salah satu kasus kejahatan atau tindak pidana yang melibatkan anak paling menonjol di Bekasi dilakukan oleh bocah berusia tujuh tahun. terjadi di kawasan di Bekasi Utara.YI, bocah kelas 1 SD tega membunuh teman mainnya sendiri anak usia 6 tahun dengan cara menenggelamkan ke danau buatan di Perumahan Summarcon Bekasi. Ironisnya, motif pembunuhan itu gara-gara uang Rp 1000 Demikian pula trafficking yang dilakukan oleh anak-anak dibawah usia terhadap anak-anak yang dibawah usia juga. Kasus perkosaan disertai dengan pembunuhan secara beramairamai serperti kasus Yy di Sumatra Selatan dll.Pidana penjara terhadap Anak hanya digunakan sebagai upaya terakhir. Jika tindak pidana yang dilakukan Anak merupakan tindak pidana yang diancam dengan pidana mati atau pidana penjara seumur hidup maka anak dijatuhi pidana penjara paling lama 10 (sepuluh) tahun. Anak yang belum berusia 14 (empat belas) tahun tidak boleh dijatuhi hukuman penjara, hanya dapat dikenai tindakan.Pidana pembatasan kebebasan yang dijatuhkan terhadap Anak paling lama 1/2 (satu perdua) dari maksimum pidana penjara yang diancamkan terhadap orang dewasa.Ketentuan mengenai pidana penjara dalam KUHP berlaku juga terhadap Anak sepanjang tidak bertentangan dengan Undang-Undang ini.Anak yang telah menjalani $1 / 2$ (satu perdua) dari lamanya pembinaan di LPKA dan berkelakuan baik berhak mendapatkan pembebasan bersyarat.Anak layak dijatuhi pidana penjara jika melakukan tindak pidana berat dan disarankan agar penjatuhan pidana penjara diperberat menjadi 15 tahun dan pidananya seyogyanya dikurangi sepertiga dari pidana untuk dewasa.sebagaimana yang diatur di dalam KUHP dahulu dan jika tindak pidananya berat/sadis anak yang belum usia 14 tahun pun disarankan dapat dijatuhi pidana penjara.
\end{abstract}

Kata kunci: hukuman, kejahatan, anak

161 I Pelita - Jurnal Penelitian dan Karya Ilmiah 


\section{A. PENDAHULUAN}

Sepanjang bulan Januari sampai dengan bulan Mei 2013, sebanyak 32 anak di bawah umur di wilayah hukum Kota Bekasi terlibat kejahatan tindak pidana berbagai kasus. Selama kurun waktu itu pula, sebanyak 11 anak menjadi korban kejahatan baik sesama anak di bawah umur maupun orang dewasa.Mulai tindak pidana ringan hingga berat, sepertikasusnarkoba.penganiayaan, pencurian, maupun tindak pidana pencabulan. Pada tahun 2012 Kejaksaan mencatat sebanyak 74 anak dalam kaitannya kasus anak berhadapan hukum.Salah satu kasus kejahatan atau tindak pidana yang melibatkan anak paling menonjol di Bekasi dilakukan oleh bocah berusia tujuh tahun. terjadi di kawasan di Bekasi Utara.YI, bocah kelas 1 SD tega membunuh teman mainnya sendiri usia 6 tahun dengan cara menenggelamkan ke danau buatan di Perumahan Summarcon Bekasi. Ironisnya, motif pembunuhan itu gara-gara uang Rp $1000^{1}$ Demikian pula trafficking yang dilakukan oleh anak-anak dibawah usia terhadap anakanak yang dibawah usia juga. ${ }^{2}$

Di Desa Kasie Kasubun, Kecamatan Padang Ulak Tanding, Kabupaten Rejang Lebong, Bengkulu, masih menjadi perhatian masyarakat Indonesia. Yuyun diperkosa secara bergantian oleh 14 remaja berusia di bawah 20 tahun, setelah diperkosa tubuh Yuyun juga dibuang ke jurang sedalam lima meter.Meskipun para pelaku sudah tertangkap, namun tetap saja kasus ini tidak begitu saja hilang. Tak hanya keluarga $Y$, masyarakat Indonesia juga ikut berduka dan menangisi kepergian bocah malang yang masih duduk di kelas II SMP Negeri 5 Rejang Lebong. ternyata kasus kematian Yuyun bukanlah kasus kejahatan seksual yang terakhir. Setelah kematian $Y$, masyarakat pun dikejutkan dengan kasus pemerkosaan lain. ${ }^{3}$ Majelis hakim PN Curup, Rejang Lebong yang menjatuhkan vonis hukuman 10 tahun penjara kepada masing-masing 7 terdakwa pelaku pemerkosa dan pembunuhan Yuyun, siswa SMPN 5 Padang Ulak Tanding."Kita menghargai keputusan menjelis hakim PN Curup Rejang Lebong, yang menjatuhkan hukuman 10 tahun penjara kepada para

\footnotetext{
${ }^{1}$ Adi Nugroho 2013 http://m.merdeka.com. 30 Juli 2013

${ }^{2}$ Agustin Widjiastuti www.beritametro.co.id 22 Oktober 2013

${ }^{3}$ Diperkosa dan dibunuh oleh 14 ABG, inilah 5 fakta terbaru kasus pembunuhan Yuyun. Bintang.com, Jakarta.
} 
terdakwa pemerkosa dan pembunuh Yuyun, karena vonis yang diberikan sesuai tuntutan jaksa penuntut umum (JPU)."

Menurut Psikolog Adelina Syarief, SE, Mpsi remaja yang melakukan perilaku menyimpang dalam hal ini yaitu kenakalan remaja disebabkan dari diri sendiri atau lingkungan."Penyebabnya bisa dari sifat bawaan atau dari keluarga, misalnya orangtua yang terlalu sibuk, kurangnya komunikasi atau perceraian.Anak yang sudah merasa tidak nyaman dalam rumah maka mudah terpengaruh lingkungan misalnya ajakan teman yang membuatnya melakukan hal negatif. Kenakalan remaja yang kerap terjadi terdiri dari empat jenis yaitu: ${ }^{4}$

\section{1) Tawuran atau perkelahian antar pelajar}

Perkelahian termasuk jenis kenakalan remaja akibat kompleksinya kehidupan kota yang disebabkan karena masalah sepele. Tawuran pelajar sekolah menjadi potret buram dalam dunia pendidikan Indonesia. Pada 2010, setidaknya terjadi 128 kasus tawuran antar pelajar. Angka itu melonjak tajam lebih dari 100 persen pada 2011, yakni 330 kasus tawuran yang menewaskan 82 pelajar. Pada Januari-Juni 2012, telah terjadi 139 tawuran yang menewaskan 12 pelajar.

\section{2) Penyalahgunaan narkotika, obat-obat terlarang dan minuman keras}

Kenakalan/kejahatan remaja ini dapat menimbulkan tindakan kriminal lainnya seperti pemerkosaan, pembunuhan, pencurian dan perampokan.Menurut Psikolog Adelina Syarief SE, Mpsi, penggunaan narkoba akan memicu timbulnya tindakan kriminal lainnya.Masa remaja merupakan periode transisi dari anak menuju dewasa. Pada usia ini kerap ditemukan perilaku berisiko yang bisa jadi mengarah ke tindakan kriminal. Kenakalan remaja merupakan perilaku menyimpang yang dilakukan sesearang usia 1419 tahun yang menimbulkan masalah atau keonaran dalam masyarakat.Kenakalan remaja disebabkan oleh dua faktor yaitu subjektif (dari diri sendiri) dan objektif (dari lingkungan).Menurut Psikolog Adelina Syarief, SE, Mpsi, remaja yang melakukan perilaku menyimpang dalam hal ini yaitu kenakalan remaja disebabkan dari diri sendiri atau lingkungan."Penyebabnya bisa dari sifat bawaan

\footnotetext{
${ }^{4}$ http://health.liputan6.com/read/688614/berbagai-perilaku-kenakalanremaja-yang-mengkhawatirkan
} 
atau dari keluarga misalnya orangtua yang terlalu sibuk, kurangnya komunikasi atau perceraian,"l Anak yang sudah merasa tidak nyaman dalam rumah maka mudah terpengaruh lingkungan misalnya ajakan teman yang membuatnya melakukan hal negatif.

\section{3) Hubungan Seksual atau Seks pra nikah}

Fenomena kasus seks di luar nikah di Indonesia menurut Direktur Bina Kesehatan Anak Kementerian Kesehatan Republik Indonesia, dr. Elizabeth Jane Soepardi, MPH mengalami peningkatan."Walaupun peningkatannya sedikit namun jumlahnya terbilang banyak yaitu sebanyak 14,6 persen pada pria dan 4,5 persen pada perempuan," Hubungan seks di luar nikah memicu penyebaran AIDS.

\section{4) Tindak Kriminal}

Tindak kriminal merupakan tindak kejahatan yang merugikan orang lain dan melanggar norma hukum, sosial dan agama. ${ }^{5}$

\section{a. Definisi Anak menurut Pandangan hukum Pidana dan Pandangan} Agama Islam.

Dalam kehidupan hukum di dalam suatu negara, kedewasaan selalu menjadi ukuran tanggung jawab dari sebuah perbuatan, karena hanya seseorang yang telah dewasa saja yang dianggap perbuatannya dapat dipertanggungjawabkan secara sempurna, hal ini dapat kita lihat dari beberapa ketentuan hukum yang memberikan kwalifikasi pada perbuatan yang pada prinsipnya hanya dapat dilakukan oleh mereka yang telah dewasa. Misalnya ketentuan Pasal 1320 KUHPerdata menyebutkan bahwa salah satu syarat sahnya perjanjian adalah jika subjek hukumnya cakap bertindak, pengertian cakap bertindak berhubungan erat dengan arti kedewasaan, karena menurut Pasal 1330 angka 1 KUHPerdata orang yang tidak cakap bertindak itu salah satunya adalah mereka yang belum dewasa/ minderjarigen. ${ }^{6}$ Menurut.Undang-Undang No. 11 Tahun 2012

\footnotetext{
${ }^{5}$ http://health.liputan6.com/read/688614/berbagai-perilaku-kenakalanremaja-yang-mengkhawatirkan
}

${ }^{6}$ Adi Nugroho 2013 http://m.merdeka.com. 30 Juli 2013

164 I Pelita - Jurnal Penelitian dan Karya Ilmiah 
tentang Sistem Peradilan Pidana AnakBatas usia anak tidak lebih dari 18 tahun atau belum pernah kawin.

Menurut Fiqih Islam batasan seseorang mulai dibebani kewajiban kewajiban hukum syar'i didalam ilmu fiqih, Baligh/dewasa ditandai dengan beberapa keadaan:

1) Adanya menstruasi (haid) bagi anak perempuan pada usia 9 tahun.

"Allah tidak menerima sholat permpuan haid, kecuali ia telah berkerudung" (H.R. Ibnu Huzaimah dari Aisyah).

2) Mimpi basah/ihtilam bagi laki-laki dan perempuan.

"Dan apabila anak-anakmu telah sampai umur dewasa maka hendaknya mereka juga minta izin seperti orang dewasa meminta izin." Menurut Qs Qashar: 14

“Telah sempurna kekuatan akalnya dan pandangannya, baligh dalam ayat ini dalam konteks kematangan seseorang.Baligh dapat diibaratkan seperti buah yang telah matang dipohonnya sehingga siap dipetik".

Sementara itu menurut Cholil Nafis secara umum Islam membagi perkembangan anak manusia melalui tiga tahapan:

1) Tahapan As shagir.

Sejak bayi hingga usia 7 tahun.pada masa ini lebih banyak menerima hak dari pada kwajibannya.

“Diangkat pena (tidak dikenakan kwajiban) pada tiga orang yaitu orang yang tidur hingga bangun. Anak kecil hingga ihtilam dan orang gila hingga berakal" (H.R. Abu Daud No. 4403 dan AlTarmizi 1423.

2) Tahapan Tamyiz.

Masa antara tujuh tahun hingga dewasa.Pada masa ini anak belum memilki kelayakan al Ada (pelaksanaan).

3) Tahapan Bulugh.

Pada masa ini dikenal dengan masa pubertas/remaja. Secara terminology al bulugh adalah habisnya masa anak anak, dimana sebuah fase dibebani tanggung jawab pelaksanaan agama.

\section{b. Perbedaan Batasan Usia Cakap Hukum dalam Peraturan Perundang- undangan}

Mengingat usia dewasa dalam berbagai Undang-undang di Indonesia berbeda-beda. Di BW usia dewasa 21 tahun, UU Perlindungan Anak, usia 18 keatas tidak dikatakan anak-anak lagi, dan berbagai macam UU lainnya. Berdasarkan beberapa ketentuan dalam peraturan 
perundang-undangan memang masih tidak ditemui keseragaman mengenai usia dewasa seseorang, sebagian memberi batasan 21 (dua puluh satu) tahun, sebagian lagi 18 (delapan belas) tahun, bahkan ada yang 17 (tujuh belas) tahun.

Ketidakseragaman batasan usia dewasa atau batasan usia anak pada berbagai peraturan perundang-undangan di Indonesia memang kerap menimbulkan pertanyaan mengenai batasan yang mana yang seharusnya digunakan.

1) Undang-Undang No. 12 Tahun 1995 tentang Pemasyarakatan

Pasal 1 angka 8Anak didik pemasyarakatan adalah:

a) Anak pidana, yaitu anak yang berdasarkan putusan pengadilan menjalani pidana di LAPAS anak paling lama sampai berumur $\mathbf{1 8}$ (delapan belas) tahun;

b) Anak negara, yaitu anak yang berdasarkan putusan pengadilan diserahkan pada negara untuk dididik dan ditempatkan di LAPAS anak paling lama sampai berumur 18 (delapan belas) tahun;

c) Anak sipil, yaitu anak yang atas permintaan orang tua atau walinya memperoleh penetapan pengadilan untuk dididik di LAPAS anak paling lama sampai berumur 18 (delapan belas) tahun.

2) Undang-Undang No. 11 Tahun 2012 tentang Sistem Peradilan Pidana $\underline{\text { Anak }}$

Batas usia anak tidak lebih dari 18 tahun atau belum pernah kawin. Hukuman yang dapat dijatuhkan kepada anak setengah dari orang dewasa.Hukuman maksimal adalah 10 tahun, jadi anak yang melakukan tindak pidana tidak boleh dijatuhkan hukuman mati. Batas umur anak nakal yang dapat diajukan ke sidang anak sebelum anak berusias 14 tahun dan belum mencapai usia 18 tahun atau belum pernah kawin.

Apabila anak melakukan tindak pidana sebagaimana telah disebut,tetapi diajukan ke sidang pengadilan setelah anak usianya lewat batas umur 18 tahun tapi belum lewat 21 tahun maka anak tetap diajukan ke sidang anak. (Pasal 20).

3) Undang-Undang No. 39 Tahun 1999 tentang Hak Asasi Manusia

Pasal 1 angka 5

Anak adalah setiap manusia yang berumur di bawah 18 (delapan belas) tahun dan belum menikah, termasuk anak yang masih dalam kandungan apabila hal tersebut adalah demi kepentingannya. 
4) Undang-Undang No. 12 Tahun 2006 tentang Kewarganegaraan Republik Indonesia

Pasal 4 huruf Warga Negara Indonesia adalah anak yang lahir di luar perkawinan yang sah dari seorang ibu warga negara asing yang diakui oleh seorang ayah Warga Negara Indonesia sebagai anaknya dan pengakuan itu dilakukan sebelum anak tersebut berumur 18 (delapan belas) tahun atau belum kawin.

5) Undang-Undang No. 44 Tahun 2008 , tentang Pornografi

Pasal 1 angka 4

Anak adalah seseorang yang belum berumur 18 (delapan belas) tahun.., Belum kawin.

Pasal 1 angka 1

6) Undang-Undang No. 23 Tahun 2002 tentang Perlindungan Anak sebagaimana terakhir diubah dengan Undang-Undang No. 35 Tahun 2014

Anak adalah seseorang yang belum berumur 18 (delapan belas) tahun, termasuk anak yang masih dalam kandungan.

Kitab Undang-Undang Hukum Perdata (Burgerlijk Wetboek) Pasal 330 yang belum dewasa adalah mereka yang belum mencapai umur genap dua puluh satu tahun dan tidak kawin sebelumnya.

7) Kompilasi Hukum Islam

Pasal 98 ayat (1)Batas umur anak yang mampu berdiri sendiri atau dewasa adalah 21 tahun, sepanjang anak tersebut tidak bercacat fisik maupun mental atau belum pernah melangsungkan perkawinan.

Dari beberapa pendapat tersebut di atas pada umumnya batasan umur yang digunakan sebagai parameter untuk menentukan kecakapan untuk berbuat dalam hukum adalah telah berumur 18 tahun. Anak yang Belum Dewasa Tidak Memiliki Legal Standing.

\section{c. Dasar dari adanya perbuatan pidana}

Dasar dari pada adanya perbuatan pidana adalah asas legaliteit, yaitu asas yang menentukan bahwa sesuatu perbuatan adalah dilarang dan diancam dengan pidana, barang siapa yang melakukannya, sedangkan dasar dari pada dipidananya pelaku tindak pidana adalah asas "tidak dipidana jika tidak ada kesalahan". Dapat pula dikatakan: Orang tidak mungkin dipertanggung jawabkan dan dijatuhi pidana kalau tidak melakukan perbuatan pidana, tetapi meskipun pelaku melakukan 
perbuatan pidana, tidaklah selalu pelaku dapat dipidanajika yang melakukan hal ini orang yang sakit jiwa.7.

\section{d. Permasalah:}

a. Apakah penjatuhan pidana saat initelah sesuai terhadap anak yang melakukan tindak pidana. berat?

b. Bagaimana solusinya untuk mengatasi kekejaman anak yang berkembang saat ini?

\section{B. ANALISIS}

1. Penjatuhan pidana maksimal saat ini belum sesuai terhadap anak yang melakukan tindak pidana berat.

Sebagaimana telah diuraikan dimuka bahwa sepanjang bulan Januari sampai dengan bulan Mei 2013, sebanyak 32 anak di bawah umur di wilayah hukum Kota Bekasi terlibat kejahatan tindak pidana berbagai kasus mulai tindak pidana ringan hingga berat kasus narkoba penganiayaan, pencurian, pembunuhan berencana, trafficking maupun tindak pidana pencabulan. Pada tahun 2012 Kejaksaan mencatat sebanyak 74 anak dalam kaitannya kasus anak berhadapan hukum. Walaupun statusnya masih anak, akan tetapi banyak yang telah melakukan kejahatan/tindak pidana yang sangat sadis seperti kasus y diperkosa beramai-ramai dan dibunuh.

Saat ini masalah proses peradilan pidana terhadap anak diatur di dalam UU RI No. 11 Tahun 2012 Tentang Sistem Peradilan Pidana Anak Jika KUHP (Kitab Undang-undang Hukum Pidana) dibandingkan dengan Undang-undang No. 11 tahun 2012, tentang Sistem Peradilan Pidana Anak yang saat ini diberlakukan lebih ringan. Batas usia anak adalah tidak lebih dari 18 tahun atau belum pernah kawin. Hukuman yang dapat dijatuhkan kepada anak setengah dari orang dewasa.Hukuman maksimal adalah 10 tahun, jadi anak yang melakukan tindak pidana berat tidak boleh dijatuhkan hukuman mati. Dalam Sistem Peradilan Pidana Anak (Undangundang No. 11 tahun 2012, tentang Sistem Peradilan Pidana Anak ) sebagaimana dimaksud pada ayat (2) huruf a dan huruf b wajib diupayakan Diversi.

Sistem Peradilan Pidana Anak meliputi, a. penyidikan dan penuntutan pidana Anak yang dilaksanakan sesuai dengan ketentuan peraturan perundang-undangan, kecuali ditentukan lain dalam Undang-

\footnotetext{
${ }^{7}$ Roeslan Saleh.,Perbuatan Pidana dan Pertanggungan Jawab Pidana Dua Pengertian Dasar Dalam Hukum Pidana, (Jakarta: Aksara Baru. 1981), hal 85.
} 
Undang ini; b. persidangan Anak yang dilakukan oleh pengadilan di lingkungan peradilan umum; c. pembinaan, pembimbingan, pengawasan, dan/atau pendampingan selama proses pelaksanaan pidana atau tindakan dan setelah menjalani pidana atau tindakan. ( Pasal 5).

Ketentuan beracara dalam Hukum Acara Pidana berlaku juga dalam acara peradilan pidana anak, kecuali ditentukan lain dalam UndangUndang ini.Identitas Anak, Anak Korban, dan/atau Anak Saksi wajib dirahasiakan dalam pemberitaan di media cetak ataupun elektronik. Hal ini menghindari stigma negatif atau pelaku tindak pidana anak malu.Identitas meliputi nama Anak, nama Anak Korban, nama Anak Saksi, nama orang tua, alamat, wajah, dan hal lain yang dapat mengungkapkan jati diri Anak, Anak Korban, dan/atau Anak Saksi.

Dalam hal tindak pidana dilakukan oleh Anak sebelum genap berumur 18 (delapan belas) tahun dan diajukan ke sidang pengadilan setelah Anak yang bersangkutan melampaui batas umur 18 (delapan belas) tahun, tetapi belum mencapai umur 21 (dua puluh satu) tahun, Anak tetap diajukan ke sidang Anak.Anak yang belum berusia 14 (empat belas) tahun hanya dapat dikenai tindakan.Ringannya perbuatan, keadaan pribadi Anak, atau keadaan pada waktu dilakukan perbuatan atau yang terjadi kemudian dapat dijadikan dasar pertimbangan hakim untuk tidak menjatuhkan pidana atau mengenakan tindakan dengan mempertimbangkan segi keadilan dan kemanusiaan.

\section{Pidana pokok bagi Anak terdiri atas:}

a. pidana peringatan; $b$. pidana dengan syarat (pembinaan di luar lembaga; pelayanan masyarakat dan pengawasan.) c. pelatihan kerja; d. pembinaan dalam lembaga; dan e. penjara.

\section{Pidana tambahan terdiri atas:}

Perampasan keuntungan yang diperoleh dari tindak pidana dan pemenuhan kewajiban adat Pidana pembatasan kebebasan diberlakukan dalam hal Anak melakukan tindak pidana berat atau tindak pidana yang disertai dengan kekerasan.Minimum khusus pidana penjara tidak berlaku terhadap Anak. Ketentuan mengenai pidana penjara dalam KUHP berlaku juga terhadap Anak sepanjang tidak bertentangan dengan UndangUndang ini.

Sebagaimana telah diuraikan di atas bahwa anak dijatuhi pidana penjara di LPKA (Lembaga Pembinaan Khusus Anak) apabila keadaan dan perbuatan Anak akan membahayakan masyarakat. Pidana penjara yang dapat dijatuhkan kepada Anak paling lama 1/2 (satu perdua) dari 
maksimum ancaman pidana penjara bagi orang dewasa.Pembinaan di LPKA dilaksanakan sampai Anak berumur 18 (delapan belas) tahun.Anak yang telah menjalani $1 / 2$ (satu perdua) dari lamanya pembinaan di LPKA dan berkelakuan baik berhak mendapatkan pembebasan bersyarat.

Mengenai perbuatan anak yang membahayakan masyarakat/perbuatannya sangat kejam diancam penjara dikurangi separuh maka penulis kurang setuju, sebaiknya dikurangi sepertiganya dari ancaman untuk orang dewasa atau ancaman pidana makimum tidak 10 tahun tetapi ancaman maksimum pidananya menjadi 15 tahun untuk exra ordinary crime seperti kasus perkosaan disertai pembunuhan sadis Yy di Sumatra Selatan.Malah ada pendapat pakar hukum prof $\mathrm{AH}$, yang menyatakan bahwa untuk kejahatan yang berat/kejam sebaiknya dipidana sebagaimana pidana untuk orang dewasa, karena tingkat kejahatanya sama dengan kejahatan oleh orang dewasa.

Contoh kasus antara lain, kasus teroris, perdagangan manusia, agar mendapat pelajaran/kapok tidak akan mengurangi perbuatan bejatnya. Menurut penulis di dalam UU No 11 tahun 2012 ini kurang memadai di dalam lamanya hukuman (hukuman maksimal 10 tahun) dibandingkan dengan yang ada di, KUHP. Di dalam KUHP maksimal pidana untuk anak ancaman pidana tertinggi adalah dikurangi sepertiga dari ancaman untuk dewasa sedangkan hukuman tertinggi adalah 15 tahun. Penulis lebih setuju pemidanaan anak yang tindakannya sangat kejam seperti melanggar beberapa pasal dalam waktu yang sama (gabungan tindak pidana/concursus) dihukum dengan hukuman yang sama dengan pidana untuk dewasa.karena lamanya pelaku tindak pidana ini di Lembaga Pemasyarakatan ini kalau kelakuannya baik akan berubah, akan pendapat pengurangan hukuman (remisi) tiap jangka waktu tertentu seperti hari raya, hari kemerdekaan RI dsb.

Pelepasan Bersyarat (Voorwaardelijke In Vrijheidstelling/VI). atau pembebasan bersyarat atau yang biasa disebut dengan proses pembinaan narapidana pada tahap keempat. Berlaku bagi narapidana yang berkelakuan baik, sehat jasmani maupun rohani. Pembinaan pelepasan bersyarat dimaksudkan untuk mengintegrasikan narapidana untuk bergaul dengan masyarakat dan latihan hidup bermasyarakat, setelah sekian lama terasing dalam tembok. 


\section{Pada dasarnya ada tiga pokok pemikiran tentang tujuan yang ingin dicapai dari suatu pemidanaan: ${ }^{8}$}

a. Untuk memperbaiki pribadi penjahat sendiri.

b. Membuat orang jera untuk melakukan tindak pidana

c. Membuat penjahat-penjahat tertentu tidak mampu untuk melakukan tindak pidana

Hugo De Groot memandang negara sebagai penjelmaan dari kehendak manusia mencari dasar pembenaran dari pemidanaan pada kehendak individu. Apa sebabnya seorang pelaku pidanaharus dipandang sebagai layak menerima akibat dari perbuatannya, telah melihat pada kehendak alam, Barang siapa melakukan kejahatan maka sudah pantas ia diperlakukan jahat pula,atau menurut sifatnya "malum passionis quod infligitur ob malum actionis" "Pemidanaan dibutuhkan tetapi tidak boleh lebih dari yang sewajarnya sesuai dengan pendapat Bentham.bahwa harus bersifat spesifik untuk tiap kejahatan dan seberapa kerasnya pidana itu tidak boleh melebihi jumlah yang dibutuhkan ${ }^{10}$. Menurut Jeremy Bentham, secara kongkrit jangan hukum pidana dikenakan/digunakan apabila groundless, needless, unprofitable or inefficacious. Demikian pula, Packer pernah mengingatkan bahwa penggunaan sanksi pidana secara sembarangan (indiscriminates by) dan digunakan secara paksa (coercively) akan menyebabkan sarana pidana itu menjadi suatu " pengancam yang utama "

Menurut penulis anak yang melakukan kejahatanseyogyanya ancaman pidananya sama dengan KUHP. (yang dulu berlaku) Hukuman yang dijatuhkan harus sesuai dengan nilai-nilai yang berlaku di dalam masyarakat, dan adil baik bagi pelaku/terdakwa maupun korban/masyarakat.

Menurut Rawls dalam teorinya, Justice as fairness (keadilan sebagai kejujuran), perlu adanya keseimbangan antara kepentingan pribadi dan kepentingan bersama. Ukuran dari keseimbangan itulah yang disebut keadilan. Keadilan merupakan nilai yang tidak dapat ditawar tawar, karena hanya dengan keadilan ada stabilitas dalam kehidupan manusia. Untuk

${ }^{8}$.P.A.F. Lamintang, 1994, Hukum Penitensier Indonesia, (Bandung: Armico, hal. 23.), 1988.

${ }^{9}$ Lamintang, Ibid.hal. 22.

${ }^{10}$ Satjipto Rahardjo., Ilmu Hukum, cet . 1, (Bandung:Alumni, 1982) hal.239

171 I Pelita - Jurnal Penelitian dan Karya Ilmiah 
menghindari benturan-benturan yang ada diperlukan hukum/ aturan sebagai wasit. Dalam masyarakat yang maju hukum, akan ditaati jika hukum mampu meletakkan prinsip-prinsip keadilan ${ }^{11}$

Apabila diterapkan pada fakta struktur dasar masyarakat, prinsip prinsip keadilan harus mengerjakan dua hal:

1. Prinsip keadilan harus memberi penilaian konkret tentang adil tidaknya institusi -institusi dan praktik- praktik institusional.

2. Prinsip-prinsip keadilan harus membimbing kita dalam memperkembangkan kebijakan-kebijakan dan hukum untuk mengoreksi ketidak-adilan dalam struktur dasar masyarakat tertentu ${ }^{12}$

Menurut J.S Mill bahwa keadilan adalah bagian dari moralitas. Bagian dari moralitas yang dilingkupi keadilan kebanyakan berdasarkan pada kegunaan ide kebahagian. Dalam bukunya yang berjudul Utilitarianism, Mill menjelaskan arti keadilan dan hubungannya dengan kegunaan. Secara etimologi, kata keadilan berasal dari hubungannya dengan perintah hukum, Recht berasal dari kata right, sinonim dari kata hukum. Pada mulanya keadilan diasosiasikan dengan hukum, keadilan adalah sesuatu yang berdasarkan hukum. Pentaatan hukum adalah keadilan. Ia memahami dengan tepat bahwa tradisional, gagasan yang abadi tentang keadilan dan ketidakadilan bertentangan dengan gagasangagasan yang berubah dan kurang berharganya mengenai kegunaan dan kepentingan. Ia dengan tepat mengamati bahwa sebenarnya tidak ada yang lebih tidak tetap dan kontroversial dari pada arti keadilan ${ }^{13}$

Mill menerapkan sintesa antara keadilan dan kegunaan. Penggabungan kebaikan individu dan kebaikan bersama menyebabkan Mill sampai pada teori penghukuman bahwa dalam memikirkan kepentingan umum, penjahat sendiri dibuat menyadari bahwa kejahatannya tidak baik, sehingga merupakan pengungkapan kemauan rasional penjahat sendiri.

Ide keadilan memperlihatkan dua hal (The idea of justice supposes two things )

1. Suatu aturan dalam tindakan/kelakuan (a rule of conduct)

2. Sanksi dari hukum. (a sentiment which sanctions the rule)

\footnotetext{
${ }^{11}$ Darji Darmodiharjo dan Shidarta, Pokok-pokok Filsafat Hukum, Cet. 2. (Jakarta: Gramedia, 2001) hal 161-162

${ }^{12} \mathrm{Ibid}$. hal 165

${ }^{13}$ Hari Chand, Modern Jurisprudence, (Kuala Lumpur: Turbo,1994). hal.. 290
} 
Dengan demikian cakupan tujuan hukum pidana untuk melindungi kepentingan perorangan, masyarakat dan negara dengan perimbangan penghormatan yang serasi antaratindakan/penugasan kejahatan disatu pihak dan tindakan aparat / penegak hukum untuk tidak sewenang wenang. Penjabaran dari salah satu cara untuk mencapai tujuan hukum pidana bahwa memidana orang/anak yang telah melakukan tindak pidana, diperlukan dasar dari pemidanaan atau Apa dasar alasan untuk membenarkan penjatuhan pidana oleh aparat/penegak hukum.

Penulis berpendapat sudah layak atau pantas jika anak melakukan tindak pidana berat harus mendapat hukuman penjara seperti melakukan tindak pidana pembunuhan berencana, perkosaan, teroris, trafficking dll, Untuk kejamnya perilaku anak seperti memperkosa lalu mencuri hartanya setelah dia membunuh korbannya.Perilaku yang demikian sadis ini memang harus diberi pembelajaran agar anak sadar akan perbuatannya.Penulis berpendapat tidak dikurangi separuh dari ancaman pidana dari orang dewasa tetapi sesuai dengan yang diatur oleh KUHP yaitu dikurangi serpertiganya.Kita juga harus melihat dari sisi korban,, dampak dari perbuatan pelaku yang sangat merugikan, baik materiil maupun immaterial.Menurut pakar hukum pidana Prof $\mathrm{AH}$, menyatakan di TVRI beberapa bulan yang lalu bahwa,sebaiknya anak yang melakukan tindak pidana berat seperti pembunuhan, perkosaan, dipidana seperti hukuman untuk dewasa.dan saya setuju dengan pendapat beliau.

Bersikap adil terhadap pelaku tindak pidana maupun terhadap korban. Selama ini kita hanya melihat dari sisi pelaku saja, pihak korban kurang mendapat perhatian.Keadilan adalah memberikan kepada masingmasing bagiannya. Kita wajib memperlakukan sesama manusia sebagaimana kita ingin diperlakukan. Harus memperhatikan keberadaan pihak lain termasuk hak hidupnya. Mewajibkan kita mengakui pihak lain sebagai mahluk yang pada hakekatnya sama nilainya dengan nilai kita sendiri. Keadilan menuntut perlakuan seperti kita ingin diperlakukan. Pemberian hukuman sebaiknya melihat pada tingkat keseriusan tindak pidana tersebut. (keadilan bagi pelaku/terpidana dan korban).Lebih spesifik sistem hukum yang sering diasumsikan sebagai sesuatu yang dengan sendirinya mengikuti dan melindungi keadilan, dapat menjadi adil atau tidak adil dalam berbagai tingkatan. 


\section{Solusinya untuk mengatasi kekejaman anak yang berkembang saat ini}

Penanggulnangan kenakalan remaja ini demikian kompleks karena masalahnya saling berkaitant. Hal ini dapat dipahami mengingat interaksi dalam masyarakat merupakan suatu sistem. Singgih D. Gunarso mengatakan dari segi hukum kenakalan remaja digolongkan dalam dua kelompok yang berkaitan dengan norma-norma hukum yaitu: (1) kenakalan yang bersifat amoral dan sosial serta tidak diantar dalam undang-undang sehingga tidak dapat atau sulit digolongkan sebagai pelanggaran hukum; (2) kenakalan yang bersifat melanggar hukum dengan penyelesaian sesuai dengan undang-undang dan hukum yang berlaku sama dengan perbuatan melanggar hukum bila dilakukan orang dewasa.

Secara ringkas penanggulangan yang dapat dilakukan dapat dikelompokan usaha-usaha penanggulangan antara lain:

\section{Pencegahan (preventif)}

\section{a. Faktor keluarga}

Keluarga adalah tempat di mana seorang anak bisa tumbuh dan berkembang dengan sempurna baik jasmani maupun rohani.Anak bisa mendapatkan perhatian, kasih sayang, juga dukungan moral dari orang tua.Namun sebaliknya, jika di dalam keluarga seorang anak tidak bisa mendapatkan hal tersebut yang terjadi adalah pelampiasan di luar rumah. Maka mereka akhirnya akan mencari perhatian dan kasih sayang dari pihak lain.Untuk itu, kewajiban sebagai orang tua agar selalu memberikan perhatian, rasa aman, nyaman, dan selalu melindungi anak-anaknya Berikan kesempatan kepada anak Anda untuk menentukan jati dirinya dalam inovasi, dan bisa belajar hidup mandiri. Jangan memanjakan anak karena hal tersebut hanya akan melemahkan karakter dan pribadinya.

\section{b. Faktor sekolah}

Orang tua mempunyai kewajiban dan tanggung jawab harus selalu memberikan arahan terhadap anaknya dalam memilih tempat sekolahnya, sebab tempat belajar yang berkualitas sangat besar dampak positifnya sekolah yang baik umumnya dapat suatu jaminan sangat berpengaruh pada masa depan. Jika kondisi sekolah tidak mendukung dapat memberikan peluang pada anak untuk berperilaku menyimpang. Walaupun tidak selalu demikian, faktor sekolah juga dapat menjadi penyebab terjadinya kenakalan pada remaja.Dalam hal ini, kualitas sekolah harus baik dan semua elemen sekolah yang ada agar senantiasa bertanggung jawab kepada anak didiknya. Kemampuan para guru sangat diperlukan dan juga peran pemerintah adalah harus cepat tanggap 
terhadap gejolak masyarakat, khususnya para remaja sedini mungkin, sebab hal ini jika tidak diantisipasi dengan cepat tanpa campur tangan semua komponen pemerintah sangat mustahil sebuah bangsa dan negara akan memiliki generasi yang kuat dan tangguh.

\section{c. Faktor lingkungan}

Faktor lingkungan / tempat tinggal adalah salah satu penyebab terjadinya sebuah karakter. Jika seorang anak hidup dalam lingkungan yang keras atau lingkungan tersebut kurang peduli terhadap sesama maka yang terjadi adalah anak akan meniru komunitas tersebut. Salah satunya adalah merokok, minum alkohal atau narkoba. alangkah prihatinnya jika kita melihat seorang anak yang belum cukup umur sudah terbiasa merokok, alkohal atau narkoba.Demikian juga dengan kemajuan di bidang tehnologi akan mempunyai dampak negatif dan positif bagi anak.perlu adanya perhatian serius terhadap anak2nya.seperti sex bebas atau perkosaan.

Setiap anak pada dasarnya dilahirkan seperti kertas putih bersih tidak ada coretan atau noda yang melekat.Anak juga dilahirkan dengan penuh kepolosan dan tidak ada dosa. Namun jika lingkungan tempat mereka tinggal tidak mendukung, pada akhirnya seorang anak atau remaja yang tumbuh di dalam lingkungan tersebut cepat atau lambat akan terpengaruh dengan kondisi lingkungan sekitarnya.

\section{d. Peran Orang Tua dan Guru serta Lingkungan}

Guru yang baik selalu mengusahakan keluarganya menjadi pintu gerbang terdepan dalam memberikan pendidikan dengan sebuah contoh, adalah cerminan komitmen dan pendalaman makna dari seorang guru. Guru harus berusaha agar keluarganya baik dan tidak korupsi agar ia dapat mengajari kepada murid-muridnya yang merupakan remaja generasi penerus bangsa memiliki moral dan ahlak baik dan tidak korupsi, berusaha tidak berbohong agar murid-muridnya sebagai remaja yang baik tidak menjadi pendusta, tidak terjabak dalam kenakalan remaja. Sebenarnya menjaga sikap dan tindak tanduk positif itu tidak hanya tanggung jawab para guru dan keluarganya, tetapi semua pihak termasuk pemerintah.

Orang pertama yang patut disalahkan mungkin adalah guru, baik guru yang ada di rumah (orang tua), di sekolah (guru), atau pun lingkungannya hingga secara tanpa disadari mencetak para remaja tersebut untuk melakukan perbuatan yang dapat digolongkan ke dalam kenakalan remaja. 
Peran orang tua yang bertanggung jawab terhadap keselamatan para remaja tentunya tidak membiarkan anaknya terlena karena terlalu dimanja. Kontrol yang baik dengan selalu memberikan pendidikan moral dan agama yang baik diharapkan akan dapat membimbing anak remaja ke jalan yang benar, bagaimana orang tua dapat mendidik anaknya menjadi remaja yang sholeh sedangkan orang tuanya jarang menjalankan sesuatu yang mencerminkan kesholehan, taat dalam menjalankan agama.

Kerja team yang terdiri dari orang tua (sebagai guru dirumah), Guru di sekolah, dan Lingkungan (sebagai Guru saat anak-anak, para remaja bermain dan belajar) harus di bentuk. diawali dengan komunikasi yang baik antara orang tua dan guru di sekolah, pertemuan yang intensif antara keduanya akan saling memberikan informasi yang sangat mendukung bagi pendidikan para remaja. Peran Lingkungan pun harus lebih peduli, dengan menganggap para remaja yang ada di lingkungannya adalah tanggung jawab bersama, tentunya lingkungan pun akan dapat memberikan informasi yang benar kepada orang tua tentang tindak tanduk si remaja tersebut dan kemudian dapat digunakan untuk mengevaluasi perkembangannya agar tidak terjebak dalam kenakalan remaja.

Terlihat betapa peran orang tua sangat memegang peranan penting dalam membentuk pola perilaku para remaja, setelah semua informasi tentang pertumbuhan anaknya di dapat, orang tuapun harus pandai mengelola informasi itu dengan benar.

\section{Usaha penindakan (represif)}

Dalam menghadapi anak yang melakukan tindak pidana berat sudah diatur di dalam Undang-undang No. 11 tahun 2012 tentang Peradilan Anak..Batas usia anak adalah tidak lebih dari 18 tahun atau belum pernah kawin. Hukuman yang dapat dijatuhkan kepada anak setengah dari orang dewasa.Hukuman maksimal adalah 10 tahun, jadi anak yang melakukan tindak pidana berat tidak boleh dijatuhkan hukuman mati. Dalam Sistem Peradilan Pidana Anak (Undang-undang No. 11 tahun 2012, tentang Sistem Peradilan Pidana Anak ) sebagaimana dimaksud pada ayat (2) huruf a dan huruf b wajib diupayakan Diversi.

Dalam hal tindak pidana dilakukan oleh Anak sebelum genap berumur 18 (delapan belas) tahun dan diajukan ke sidang pengadilan setelah Anak yang bersangkutan melampaui batas umur 18 (delapan belas) tahun, tetapi belum mencapai umur 21 (dua puluh satu) tahun, Anak tetap diajukan ke sidang Anak.Anak yang belum berusia 14 (empat belas) tahun hanya dapat dikenai tindakan.Ringannya perbuatan, keadaan pribadi Anak, atau keadaan pada waktu dilakukan perbuatan atau yang terjadi 
kemudian dapat dijadikan dasar pertimbangan hakim untuk tidak menjatuhkan pidana atau mengenakan tindakan dengan mempertimbangkan segi keadilan dan kemanusiaan.

\section{Pidana pokok bagi Anak terdiri atas:}

a. pidana peringatan; $b$. pidana dengan syarat( pembinaan di luar lembaga; pelayanan masyarakat dan pengawasan.) c. pelatihan kerja; d. pembinaan dalam lembaga; dan e. penjara.

\section{Pidana tambahan terdiri atas:}

Perampasan keuntungan yang diperoleh dari tindak pidana dan pemenuhan kewajiban adat. Pidana pembatasan kebebasan diberlakukan dalam hal Anak melakukan tindak pidana berat atau tindak pidana yang disertai dengan kekerasan.Minimum khusus pidana penjara tidak berlaku terhadap Anak. Ketentuan mengenai pidana penjara dalam KUHP berlaku juga terhadap Anak sepanjang tidak bertentangan dengan UndangUndang ini.

Sebagaimana telah diuraikan di atas bahwa anak dijatuhi pidana penjara di LPKA (Lembaga Pembinaan Khusus Anak) apabila keadaan dan perbuatan Anak akan membahayakan masyarakat. Pidana penjara yang dapat dijatuhkan kepada Anak paling lama 1/2 (satu perdua) dari maksimum ancaman pidana penjara bagi orang dewasa.Pembinaan di LPKA dilaksanakan sampai Anak berumur 18 (delapan belas) tahun.Anak yang telah menjalani $1 / 2$ (satu perdua) dari lamanya pembinaan di LPKA dan berkelakuan baik berhak mendapatkan pembebasan bersyarat.

Mengenai perbuatan anak yang membahayakan masyarakat/perbuatannya sangat kejam diancam penjara dikurangi separuh maka penulis kurang setuju, sebaiknya dikurangi sepertiganya dari ancaman untuk orang dewasa atau ancaman pidana makimum tidak 10 tahun tetapi ancaman maksimum pidananya menjadi 15 tahun untuk exra ordinary crime seperti kasus perkosaan disertai pembunuhan sadis Contoh kasus antara lain, kasus teroris, perdagangan manusia, agar mendapat pelajaran/kapok tidak akan mengurangi perbuatan bejatnya.. Penulis lebih setuju pemidanaan anak yang tindakannya sangat kejam seperti melanggar beberapa pasal dalam waktu yang sama (gabungan tindak pidana/concursus) dihukum dengan hukuman yang sama dengan pidana untuk dewasa.karena lamanya pelaku tindak pidana ini di Lembaga Pemasyarakatan ini kalau kelakuannya baik akan berubah, akan pendapat pengurangan hukuman (remisi) tiap jangka waktu tertentu seperti hari raya, hari kemerdekaan RI dsb. 
Pelepasan Bersyarat (Voorwaardelijke In Vrijheidstelling/VI). atau pembebasan bersyarat atau yang biasa disebut dengan proses pembinaan narapidana pada tahap keempat. berlaku bagi narapidana yang berkelakuan baik, sehat jasmani maupun rohani. Pembinaan pelepasan bersyarat dimaksudkan untuk mengintegrasikan narapidana untuk bergaul dengan masyarakat dan latihan hidup bermasyarakat, setelah sekian lama terasing dalam tembok.

\section{PENUTUP}

1. Kesimpulan:

a. Di dalam Undang-undang Sistem peradilan pidana anak yang saat ini berlaku sudah baik, tetapi masih kurang memadai di dalam lamanya hukuman (hukuman maksimal 10 tahun). Pidana untuk pelaku anak dikurangi sepertiga. Tetapi untuk pidana berat diberlakukan seperti yang ada di dalam KUHP atau sebagaimana hukuman untuk dewasa.Di dalam KUHP maksimal pidana untuk anak ancaman pidana tertinggi adalah dikurangi sepertiga dari ancaman untuk dewasa sedangkan hukuman tertinggi adalah 15 tahun. Pemidanaan dibutuhkan tetapi harus bersifat spesifik untuk tiap kejahatan dan seberapa kerasnya pidana itu tidak boleh melebihi jumlah yang dibutuhkan.Pemberian hukuman sebaiknya melihat pada tingkat keseriusan tindak pidana tersebut. (keadilan bagi pelaku/terpidana dan korban).

b. Adanya kerjasama antara orang tua, Guru dan Lembaga kemasyarakatan dalam menangani masalah anak.

\section{Saran}

Seyogyanya ada revisi sedikit Undang-undang Peradilan Anak dalam hal kejahatan yang sadis dilakukan oleh anak. 


\section{Referensi}

Tina Asmarawati. (tt). Sistem Peradilan Pidana di Indonesia, cet 1. Yogjakarta, Depublish, 20.

Hari Chand. (tt). Modern Jurisprudence, Kuala Lumpur: Turbo, 1994.

Singgih D. Gunarso. (tt). PsikologiRemaja. Jakarta, BPK Gunung Mulya. 1988.

Sudarsono. (tt). Kenakalan Remaja: Jakarta, Rineka Cipta. 1995.

TjiptoSubadi. (tt). Sosiologidan Sosiologi Pendidikan. Surakarta, Fairuz Media, 2009.

Lilik Mulyadi. (tt). Kapita Selekta Hukum Pidana Kriminologi dan Victimologi, cet. 1, Jakarta: Djambatan. 2004.

Lamintang. (tt). Hukum Penintentier Indonesia, cet. 1, Bandung: Armico, 1994.

Roeslan Saleh. (tt). Perbuatan Pidana dan Pertanggungan Jawab Pidana Dua Pengertian Dasar dalam Hukum Pidana, Jakarta: Aksara Baru. 1981.

Satjipto Rahardjo. (tt). Ilmu Hukum, cet . 1, Bandung: Alumni, 1982.

SoerjonoSoekanto. (tt). Sosiologi Penyimpangan. Jakarta, Rajawali. 1988.

Sr Sianturi. (tt). Asas Hukum Pidana di Indonesia dan Penerapannya, Jakarta: Alumni 1996.

Pemerintah Republik Indonesia, Undang-undang No. 11 Tahun 2012, Sistem Peradilan Pidana Anak, Jakarta, Dirjen HAM, Kementerian Hukum dan HAM RI

Website:

http://tulisanterkini.com/artikel/artikel-ilmiah/8218-upayapendidikan-agama-dalam-menanggulangi-kenakalan-siswa.html http://www.solopos.com/2015/09/14/kenakalan-remajageng-pelajar-bacok-2-mahasiswa-642316

Adi Nugroho http://m.merdeka.com.( 30 juli 2013)

Agustin Widjiastuti www.beritametro.co.id (22 Oktober 2013)

http://health.liputan6.com/read/688614/berbagai-perilakukenakalan-remaja-yang-mengkhawatirkan

Y.M. UttamoThera. 2007. Kiat Mengatasi Kenakalan Remaja.

Diambil pada tanggal 10 Nopember 2010, dari http://www.123people.Com/s/kenakalan+remaja.

Tentangiklan-iklanini

Posted on Desember 23, 2010by siswatibudiarti http://belajarpsikologi.com/kenakalan-remaja/ https:// keluarga.com/1724/beberapa-faktor-penyebabkenakalan-pada-remaja 
Edisi XIX Volume 2, Juli - Desember 2019

Jurnal Penelitian dan Karya Ilmiah

Senin, 14 September 2015 10:20

WIB Sunartono/JIBI/HarianJogja PeristiwaSh a re

http://ismiearie.blogspot.co.id/2015/05/kenakalan-remaja.html

180 I Pelita - Jurnal Penelitian dan Karya Ilmiah 